\title{
Evaluating the community-based medical education programme in a rural district hospital: The students' perspectives
}

ANTHONIO O Oladele ADEFUYE ( $\square$ AdefuyeAO@ufs.ac.za )

University of the Free State https://orcid.org/0000-0003-2380-1487

Matthew Abiodun Benedict

University of the Free State

Johan Bezuidenhout

University of the Free State

Jamiu Busari

Maastricht University

Research article

Keywords: Community-based medical education, Botshabelo District Hospital, Evaluation

Posted Date: July 10th, 2019

DOI: https://doi.org/10.21203/rs.2.11231/v1

License: (c) (i) This work is licensed under a Creative Commons Attribution 4.0 International License.

Read Full License 


\section{Abstract}

Backgrounds: The adoption of community-based medical education (CBME) into the undergraduate medical curriculum is in line with the SPICE model for medical curriculum proposed by Harden and colleagues. Students are the consumers of medical education and are, thus, the ideal evaluators of the efficacy of their own course and learning environment. To evaluate the quality of the CBME programme in Botshabelo District Hospital (BDH), this study investigated student's perceptions of their experience during their $\mathrm{CBME}$ training at $\mathrm{BDH}$. In addition, suggestions on how to enrich students' experience during the CBME posting was obtained from the participants. Methods: This research was designed as a qualitative (Ethnographic) study that used a questionnaire survey to qualitatively explore the perceptions of fourth-year undergraduate medical student at BDH. Results: Of the 120 questionnaires distributed, 84 were returned, giving a response rate of $70.0 \%$. When asked to indicate what they liked or disliked about their CBME training, "Good educators/staff" and the "Attitude of some doctors" were the themes that scored highly (25.1\% and $19.4 \%$ ) in the "likes" and "dislikes" category respectively. Some of the major challenges faced during the CBME training at $\mathrm{BDH}$ included; Exposure to new learning environment (14.2\%); Clinical practice context (12.6\%) and; Language barrier (7.2\%). Participants stated that they gained knowledge of how to perform certain clinical procedures and acquired core clinical skills in the areas of formulating management and managing some medical emergencies during their training at $\mathrm{BDH}$. Increasing the duration of training (25.6\% coverage) was suggested as a major way to enrich students" experience during the training at BDH. Conclusions: Findings from this study reveal that CBME is a valuable pedagogical tool to enhance learning in undergraduate medical education and that more work is required to improve the quality of $\mathrm{CBME}$ training in $\mathrm{BDH}$. We believe that the findings from this study will inform future planning of CBME training programmes in $\mathrm{BDH}$.

\section{Background}

In response to the diverse changes to the practice of medicine and the reorganization of healthcare systems, the curriculum of undergraduate medical education in many countries has undergone extensive revision.(1) In addition, the ongoing changes to the role of physicians and the needs of patients' have generated the need to modify undergraduate medical curricula and introduce new teaching and learning strategies such as community-based medical education (CBME). $(1,2)$

The adoption of CBME in to the undergraduate medical curriculum aligns with the SPICE (Student centred, Problem based, Integrated, Community based, Electives and Systematic) model for medical curriculum proposed by Harden et al. (1984). (3) Worley and Couper (2013) defined CBME as "medical education that is based outside a tertiary or large secondary level hospital (and which) is focussed on the care provided to patients both before the decision to refer to a tertiary hospital and after the decision to discharge the patient from such care".(4) Numerous benefits of CBME have been reported in the literature and include; promoting a more patient-orientated perspective; offering a broader range of learning opportunities for students to acquire knowledge, skills and attitudes; and providing students with the opportunity to learn about general and family medicine practice in a rural setting. $(4,5)$ 
In order to harness the numerous benefits of CBME, the faculty of health Sciences University of the Free State introduced CBME into its undergraduate medical curriculum in 2015 through a collaborative community based education initiative titled "Ho-Rutana" (teach-each-other) initiative in Springfontein (Xhariep district of the Free State).(6) As part of the CBME programme, all fourth-year medical students were expected to spend two weeks in Botshabelo District Hospital (BDH) and its clinics (one week in the district hospital, one week in the clinics). The purpose of the initiative was to offer students the opportunity to learn about the differences in health care delivery in rural areas and to gain an insight into primary health care $(\mathrm{PHC})$ as the backbone of the South African health system. Since the inclusion of CBME into the curriculum and the commencement of $\mathrm{CBME}$ programme in $\mathrm{BDH}$, no known study has evaluated the quality of the $\mathrm{CBME}$ training at $\mathrm{BDH}$.

Programme evaluation is a systematic method for collecting, analysing, and using information to answer basic questions about a programme (7), and it is a valuable tool for programme managers seeking to strengthen the quality of their programmes and improve outcomes.(8) Students are the consumers of medical education and are, thus, ideal evaluators of the efficacy of their own course and learning environment.(9) To evaluate the quality of the CBME programme in $\mathrm{BDH}$, this present study explored students' perceptions of their experience during their CBME training at BDH. In addition, suggestions on how to enrich the educational experience of the students during the CBME posting was also investigated.

\section{Methods}

This research was designed as a qualitative (Ethnographic) study that made use of a structured evaluation form (Appendix I) to obtain written statement from participants' describing their experience during their CBME training at BDH. The structured evaluation form (i.e. questionnaire) used in this study was self-administered and was distributed manually (hard copy) to participants. The form consisted of only open-ended questions grouped into four main sections:

Section A obtained information on what the participants' liked or disliked about the CBME programme in $B D H$, section $B$, highlighted the challenges the participants' faced during the $C B M E$ training in $B D H$, and in section $\mathrm{C}$, participants were asked to report in their own words, what they learnt during the CBME training at $\mathrm{BDH}$. In the last section, section $\mathrm{D}$, the participants were given the opportunity to provide suggestions on how students' experiences could be enriched during the CBME training in BDH.

This method of qualitative data collection using a questionnaire was chosen out of convenience, as it was impracticable to conduct face-to-face interviews for all of the participants in the study, and achieve this within the specified timeframe allocated to the study. In addition, our goal was to obtain extensive and diverse information from our target population, which made this strategy an ideal method to obtain rich and informative data from such a large number of respondents.

\section{Study population}


The target population included all registered fourth-year undergraduate medical student of the University of the Free State that undertook the CBME training in BDH during the 2017/2018 academic year. The survey population consisted of individuals who voluntarily agreed to participate in the study after reading and signing the informed consent forms. The sample consisted of 120 registered fourth-year undergraduate medical students.

\section{Data collection and analysis}

Prior to the official start of this study, a pilot study was conducted to test the suitability of the study's design and methods, the chosen data collection method and the overall structure of questionnaire. The pilot study consisted of four registered year $4 \mathrm{MBCHB}$ students who voluntarily consented in filling the questionnaire. The findings of the pilot study confirmed the feasibility of the main study, as the participants in the pilot study did not recommend changes to the structured questionnaire. The result of the pilot study was included in the final results.

Placement supervisors who assisted in both the dissemination and collection of the evaluation forms aided data collection. Data was collected at the end of the last day of the two weeks CBME training programme in $\mathrm{BDH}$. Responses to the open-ended questions were read and re-read by the investigators, to familiarise themselves with the content. Content analysis was done using NVivo 12 software (QRS International Pty Ltd, Australia). Thematic analysis (Inductive) formed the cornerstone of the analysis, and specific attention was given to patterns and emerging themes. The five topmost themes with the highest percentage coverage of for each category where plotted and presented as bar chart.

\section{Results}

This study achieved a response rate of $70.0 \%$, as 84 of the initial 120 questionnaire were returned.

\section{Participants" "likes" or "dislikes" of the CBME programme in BDH}

To obtain data on what participants' like or dislike about the CBME training in BDH, participants' were requested to responds to the question "What do you like or dislike about the CBME training at $B D H$ ?" Content analysis of participants' written responses gave ten core themes for "likes" and six core themes for "dislikes" respectively. The five topmost themes with the highest percentage coverage for each category are presented in Figure 1. As seen in Figure 1, "Good educators/staff" had the highest coverage $(25.1 \%)$ in the "likes" category while "the attitude of some doctors" had the highest coverage $(19.4 \%)$ in the "dislikes" category.

Other identified themes include working independently (5.5\%); Good organisation (3.4\%); Learning environment (1.7\%); Clinical meetings/ programmes (1.3\%); Good inter-professionalism (0.5\%) - "likes" category and Poor teaching technique - "dislikes" category 
Analysis of participants' accounts of the challenges encountered during their CBME training in BDH yielded eleven themes. Majority of the challenges reported by the participants centred on challenges faced when exposed to a new learning environment, presented under the theme exposure to new learning environment (14.2\%) (Figure 2).

Other challenges reported by the participants are represented under the following themes; Organisation (5.8\%); Group dynamics (5.2\%); Insufficient background medical knowledge (5.2\%); Limited hospital resources (3.2\%); Filling log book (3.6\%); and Limited time for rotations $\quad(1.4 \%)$.

\section{What participants learnt during the CBME training in $B D H$}

Participants were asked to report in their own words, what they learnt during the CBME training at BDH. Results as presented in Table 1 gave twelve themes. The highest ranked theme was "learning how to perform certain medical/surgical procedures (12.8\%) (Table 1).

\section{Suggestions on how student's experience can be enriched during CBME at BDH}

Participants' suggestion on how to further enrich students' experience during the CBME at BDH was grouped into nine major themes as presented in Table 2. Increasing the duration of CBME training at BDH was ranked highest with $25.6 \%$ frequency. Participants also commented on the need to review the logbook and the improvement of the living conditions as ways in which students experiences can be enhanced during the CBE training. Furthermore, participants also made mention of the need for better organisation and the need to review the clinic visits (Table 2).

\section{Discussion}

It has been argued that programme evaluation is an essential indicator of programme effectiveness.(10) In the education sector, evaluation is widely used to generate information for policy, planning, design, implementation, assessment of result, improvement/learning, accountability and public communication. (11) According to Kreber et al. (2001), determining students' perceptions of staff's teaching performance; assessing students' learning; and inviting student ratings are some of the approaches to programme impact evaluation.(10) In this present study, we evaluate the quality of the community-based medical education (CBME) programme in Botshabelo district hospital (BDH) in the Free State, South Africa, by obtaining students perception on their experience during their CBME training.

Satisfaction (and dissatisfaction) refers to the evaluation of a service and comprises cognitive, affective, and attitudinal components.(12) Higher satisfaction is associated with consumer loyalty and has positive effect.(13) Similarly, understanding students' sources of satisfaction and dissatisfaction has been highlighted as one major way to enhance students' learning experience.(14) Students' satisfactions has been reported to have had a positive effect on students' school performances, personalities, and attitudes toward learning, and dissatisfaction to have had a negative effect on students' personalities and attitudes towards learning.(15) It can be presumed that factors that culminate into students satisfaction 
are what students "like" about their programme and those that precipitate dissatisfaction are their "dislikes" about the programme. Prior studies have shown a strong positive correlation between liking the instructor/teaching experience and student satisfaction. $(16,17)$ Findings in this study reveal that participants liked the "Good educators/staff" they encountered during their CBME training in BDH. Their comments reflected that the educators were friendly, knowledgeable and enthusiastic about teaching:

- Doctors were very friendly and helpful, their knowledge about the topics was also very good

- All the doctors and nurses were friendly and enthusiastic about teaching us

It is therefore probable that the liking of good educators/staff promote satisfaction and precipitate positive attitude to learning. In addition, participants conveyed that they liked the fact that training was practical and hands-on. Some of the comments used to reflect this included:

- I loved how it is practical and we see and do what we are actually gonna do one day

- More hands-on experience, not as academic, which is nice

Beelick (1973) reports that interesting schoolwork is a source of student satisfaction.(15) It is thus probable that some participants of this study perceived the "hands-on experience" as interesting work and derived satisfaction from it. The findings that "attitude of some doctors/educators" was reported as a "dislike" and probably a source of dissatisfaction in the CBME training at BDH (Figure 1), correlates with similar findings by Beelick (1973) who reports that teacher's behaviour is a major source of student dissatisfaction.(15) Attitudes such as lateness to work, lack of organisation, inability to work under pressure and rudeness to student and patients were reported:

- Late doctors

- Some of the doctors were not so organised so that also resulted in us standing around a lot

- Negative attitude by some doctors when it becomes overwhelming

- ..... f felt that one doctor was being unnecessarily rude to us as students but also to his patients

- At OPD DrX treated patients very poorly including shouting and swearing at them...

- Certain doctors that showed no compassion towards their patients.

Attending numerous redundant clinics, poor organisational logistics, and time constraints were all reported as "dislikes":

- I would have much rather rotated in one clinic through the different parts of the clinic than go to 13 clinics and only repeat scripts

- The clinic times were a bit redundant

- The clinic visits because we wrote scripts mostly and thus the time spent there wasn't very educational 
- Sometimes we waited around a lot in the mornings before we started working

- It was too little time in BDH, would like it if it was longer

Logbooks are widely used in medical education as an evaluation tool to assess students' progress towards objectives.(18) Numerous studies have reported on the use and value of logbook in medical education. $(19,20)$ However, some participants of this study stated that the logbook hindered student learning and might not be a true reflection of attained objectives:

- Though the purpose of the logbook is understood, it deters proper/effective learning, i.e. instead of trying to actually grasp/understand/perform something, the signature is chased to fill the logbook

- The logbooks are unnecessary - we must write down all the patients that we saw, in our logbooks, according to the logbook - we might as well not have seen the real patients

According to Raghoebar-Krieger et al. (2001) and Patil (2002) supervision and feedback and using logbooks as an interactive vehicle between students and tutors are important mechanism to foster student learning and optimize students' use of logbooks. $(18,19)$ It is suggested that educators in the CBME programme at BDH should make use of the aforementioned mechanism to foster meaningful learning with the use of logbooks during the CBME training.

Although community-based teaching has many potential advantages, many important challenges also exist.(21) Findings by this study reveals that challenges faced by student during their CBME posting in $\mathrm{BDH}$ was grouped under eleven themes. It has been reported that student perception of their learning environments impact on the way students cope in these learning environments and consequently affect their learning.(22) In this study, participants perceive their new learning environment as the utmost challenge faced during their CBME training at BDH (14.2\%) (Figure 2):

- Adjusting to a setting that is very different from tertiary institution

- Having to think fast and on my feet at casualties and clinics make it a bit tough...

- Adapting to an environment of working full day...

- Conforming to an 8 to 4 workday

Some participants reported insufficient background medical knowledge as a challenge (5.2\%), while others stated that coping with group dynamics was challenging for them (5.2\%):

- Meeting patient expectations when I only have a limited pool of knowledge

- Negative challenge - group dynamics amongst students 
Other reported challenges by the participants include Clinical practice context (12.6\%); Personal challenges (7.5\%) and; Language barrier (7.2\%):

- Learning to differentiate between urgent/emergent and "over-reacting" patients, when to refer and when not to

- It's silly, but all the travelling makes me sleepy during the day

- The only challenge was to get up so early in the morning

- The language barrier was hard to break

- There was a communication problem with some of the patients due to a language barrier...

- The language barrier was also a challenge

Gomes and Golino (2014) reports that students' self-reported perceptions on their academic processes are a type of metacognition: academic metacognitive knowledge.(23) Performing a self-reflection on their own learning empowers learners and leads to students gaining increasing control over their learning. (24) In this present study, participants' were requested to do a self-reflection and give a self-reported perception in their own words, what they learnt during the CBME training. Data presented in Table 1 suggests that participants responses can be discussed under twelve themes. According to Habbick \& Leeder (1996), one of the major benefits of CBME is to offer students a broader range of learning opportunities to acquire knowledge, skills and attitudes.(5) Similarly, participants of this study stated that they gained knowledge of how to perform certain clinical procedures and acquired core clinical skills in the areas of formulating management and managing some medical emergencies during their $\mathrm{CBME}$ training at $\mathrm{BDH}$ (Table 1):

- I gained knowledge about medical treatment and how to perform certain procedures

- For the first time I could formulate management of a patient

- How to present a patient

- How to make proper notes

- I learned that sometimes clinical evaluation is more important than x-rays or CT scans as these are not always available'

- How to handle different casualty cases

- Managing patients in an acute setting like casualties

In addition, promoting a more patient-orientated perspective and deepening the range of health and illness issues and the working of the health and social services has been reported as benefits of CBME. 
(5) Hence, participants of this study reported gaining knowledge in the area of patient care, management of common disease and operations of the the primary health care system:

- Approach to a patient from our role in primary healthcare

- How to be a kind doctor and listen to patients

- I learned many things including treatment of HPT, DM, TB and HIV, all fields where I felt my knowledge was lacking

- I learned how primary health care facilities operate

Furthermore, participants reported gaining knowledge on the role of a general practitioner (GP) and family medicine practice (Table 1):

- I learnt how a GP must function

- I learnt what Family medicine entails and how to function in a primary health care facility

This corroborates prior reports by Worley and Couper (2013) which suggests that students can learn about general and family medicine during CBME training. (25) Finally, participants' suggestions on how to further enrich students' experience during the CBME training at BDH revealed nine core themes (Table 2). Increasing the duration of training had the highest percentage coverage $(25.6 \%)$ suggesting that the majority of the statements given by the participants fall under this theme and that majority of them advocate for increasing the duration of training at BDH. Other suggestions given include Improved organisation (10.4\%); Inclusion of formal educational programme in the training (8.4\%) and; Improving doctors' attitude (6.1) (Table 2).

\section{Conclusions}

At present, CBME is recognized as an important method available in medical education to foster medical knowledge and skills needed by medical graduates in the community. Programme evaluation is a valuable tool used by programme managers to strengthen the quality of their programmes and improve outcomes.(8) Obtaining student perception of learning, staffs' teaching performance and programme appraisal are considered as approaches to programme impact evaluation. It is our assumption that the findings from this study will inform future planning of the CBME training programme in BDH.

\section{Declarations}

\section{Ethical considerations}


Ethical approval was obtained from the Health Science Research Ethics Committee of the University of the Free State (Ethical Clearance No: ETOVS 08/2010).

\section{Consent for publication}

Not applicable

\section{Availability of data and material}

All data generated or analysed during this study are included in this published article [and its supplementary information files]

\section{Competing interest}

None

\section{Funding}

None

\section{Authors' contributions}

AA collated and analysed the data and wrote the manuscript, MB conceptualised, supervised the execution of the study, and reviewed the manuscript, JB and JB both reviewed the manuscript and provided expert input.

\section{Acknowledgement}

The researchers wish to thank all the year $4 \mathrm{MBCHB}$ students who participated in this study.

\section{References}

1. Yakhforoshha A, Oveisi S, Sarchami R, Mahmoodi-Bakhtiari B. Community-based medical education in action: primary care physicians' perceptions. European Journal for Person Centered Healthcare. 2017;5(2):245-52.

2. Dent J. The developing role of Community-Based Medical Education. MedEdPublish. 2016;5.

3. Harden RM, Sowden S, Dunn WR. Educational strategies in curriculum development: the SPICES model. Med Educ. 1984;18(4):284-97.

4. Worley P, Silagy C, Prideaux D, Newble D, Jones A. The parallel rural community curriculum: an integrated clinical curriculum based in rural general practice. Med Educ. 2000;34(7):558-65.

5. Habbick B, Leeder S. Orienting medical education to community need: a review. Med Educ. 1996;30(3):163-71. 
6. Faculty of Health Sciences University of the Free State. Faculty of health sciences rural community initiative student guide 2019 school of clinical medicine. Bloemfontein: University of the Free State press.; 2019.

7. US Department of Health Human Services. Administration for children and families, administration on children, youth and families. In: Department of Health Human Services, editor. The Program Manager's Guide to Evaluation. Washington, DC. 2003.

8. Metz AJ. Why conduct a program evaluation? Five reasons why evaluation can help an out-of-school time program. Research-to-Results Brief Publication 2007-31, 1. 2007;4.

9. Walker L, Haldane J, Alexander D. A medical curriculum: evaluation by final-year students. Med Educ. 1981;15(6):377-82.

10. Kreber C, Brook P, Policy E. Impact evaluation of educational development programmes. IJAD. 2001;6(2):96-108.

11. McDavid JC, Huse I, Hawthorn LRL. Program Evaluation and Performance Measurement: An Introduction to Practice: SAGE Publications; 2018.

12. Petruzzellis L, d'Uggento AM, Romanazzi S. Student satisfaction and quality of service in Italian universities. Managing service quality: An international journal. 2006;16(4):349-64.

13. Green HJ, Hood M, Neumann DL. Predictors of student satisfaction with university psychology courses: A review. Psychology Learning \& Teaching. 2015;14(2):131-46.

14. Stubbs M. 5 top tips to enhance your students' experience 2013 [Available from: https://www.jisc.ac.uk/blog/5-top-tips-to-enhance-your-students-experience-11-mar-2013.

15. Beelick DB. Sources of student satisfaction and dissatisfaction. The Journal of Educational Research. 1973;67(1):19-22.

16. Hermans CM, Haytko DL, Mott-Stenerson B. Student Satisfaction in Web-Enhanced Learning Environments. Journal of instructional pedagogies. 2009;1.

17. Berbegal Mirabent J, Mas Machuca M, Marimón Carvajal F, editors. The impact of the lecturer experience on the student satisfaction. Proceedings book of the 2nd International Conference on Quality Engineering and Management, 2016; 2016.

18. Raghoebar-Krieger H, Sleijfer D, Bender W, Stewart R, Popping R. The reliability of logbook data of medical students: an estimation of interobserver agreement, sensitivity and specificity. Medical Education-Oxford. 2001;35(7):624-31.

19. Patil N, Lee P. Interactive logbooks for medical students: are they useful? Med Educ. 2002;36(7):6727.

20. Paice E, Moss F, West G, Grant J. Association of use of a log book and experience as a preregistration house officer: interview survey. BMJ. 1997;314(7075):213.

21. Murray E, Modell M. Community-based teaching: the challenges. Br J Gen Pract. 1999;49(442):395-8.

22. Gijbels D, Van de Watering G, Dochy F, Van Den Bossche P. New learning environments and constructivism: The students' perspective. Instructional science. 2006;34(3):213-26. 
23. Gomes CMA, Golino HF. Self-reports on students' learning processes are academic metacognitive knowledge. Psicologia: Reflexão e Crítica. 2014;27(3):472-80.

24. Suskie L, Banta TW. Assessing Student Learning: A Common Sense Guide: Wiley; 2010.

25. Worley PS, Couper ID. In the community. In: JA Dent \& RM Harden, editor. A Practical Guide for Medical Teachers. Edinburgh: Elsevier; 2013.

\section{Tables}

Table 1: Knowledge gained during the CBME training in $\mathrm{BDH}$ 


\begin{tabular}{|c|c|c|}
\hline Themes & $\begin{array}{c}\text { Percentage } \\
\text { coverage } \\
(\%) \\
\end{array}$ & Some excerpt from participants responses \\
\hline $\begin{array}{l}\text { How to perform } \\
\text { certain } \\
\text { medical/surgical } \\
\text { procedures }\end{array}$ & 12.8 & $\begin{array}{l}\text { I gained knowledge about medical treatment and } \\
\text { how to perform certain procedures } \\
\text { Learnt how to administer spinal anaesthetic } \\
\text { Learnt how to insert a suprapubic catheter } \\
\text { I also learned how to do Lumbar puncture and } \\
\text { spinal anaesthesia } \\
\text { Medical procedures e.g. lumber punches }\end{array}$ \\
\hline $\begin{array}{l}\text { Acquiring core clinical } \\
\text { skills }\end{array}$ & 9.4 & $\begin{array}{l}\text { For the first time I could formulate management of } \\
\text { a patient } \\
\text { How to present a patient } \\
\text { How to make proper notes } \\
\text { I learned that sometimes clinical evaluation is more } \\
\text { important than x-rays or CT scans as these are not } \\
\text { always available }\end{array}$ \\
\hline $\begin{array}{l}\text { Dosage of commonly } \\
\text { used drugs }\end{array}$ & 8.5 & $\begin{array}{l}\text { Doses of lots of common drugs } \\
\text { I learnt important drug dosages } \\
\text { Medication, indications and dosages }\end{array}$ \\
\hline $\begin{array}{l}\text { The operations of the } \\
\text { primary health care } \\
\text { system. }\end{array}$ & 7.5 & $\begin{array}{l}\text { I learned how primary health care facilities operate } \\
\text { I learnt a lot about primary health care... } \\
\text { I learned how the hospital worked logistically and } \\
\text { how it functions. }\end{array}$ \\
\hline $\begin{array}{l}\text { Management of } \\
\text { common diseases }\end{array}$ & 4.9 & $\begin{array}{l}\text { I learned many things including treatment of HPT, } \\
\text { DM, TB and HIV, all fields where I felt my } \\
\text { knowledge was lacking } \\
\text { Correct management of chronic diseases e.g. } \\
\text { hypertension, diabetes, heart failure, etc. is visited } \\
\text { After one day in clinics, I memorised the HPT } \\
\text { regimen }\end{array}$ \\
\hline $\begin{array}{c}\text { Management of } \\
\text { medical emergencies }\end{array}$ & 4.6 & $\begin{array}{l}\text { How to handle different casualty cases } \\
\text { Managing patients in an acute setting like } \\
\text { casualties } \\
\text { How to treat emergency cases... }\end{array}$ \\
\hline $\begin{array}{l}\text { Inter- } \\
\text { professionalism/Team } \\
\text { work }\end{array}$ & 3.7 & $\begin{array}{l}\text { I learned about teamwork... } \\
\text { How a good professional team operates } \\
\text { How to work in a team }\end{array}$ \\
\hline Patient care & 2.1 & $\begin{array}{l}\text { Approach to a patient from our role in primary } \\
\text { healthcare } \\
\text { How to approach different types of personalities... } \\
\text { How to be a kind doctor and listen to patients }\end{array}$ \\
\hline $\begin{array}{l}\text { Role of a GP and } \\
\text { family medicine } \\
\text { practice }\end{array}$ & 1.9 & $\begin{array}{l}\text { I learnt what Family medicine entails and how to } \\
\text { function in a primary health care facility } \\
\text { I learnt how a GP must function }\end{array}$ \\
\hline $\begin{array}{c}\text { How to make clinical } \\
\text { decision/judgement }\end{array}$ & 1.8 & $\begin{array}{l}\text { Clinical judgement } \\
\text { I learnt how to clinically assess a patient and make } \\
\text { my own diagnosis }\end{array}$ \\
\hline Self-confidence & 1.0 & $\begin{array}{l}\text { Confidence in my own skills and abilities } \\
\text { Confidence }\end{array}$ \\
\hline
\end{tabular}


Medical education leadership

0.41 Dr T and Dr B are a good blend of leadership styles

Table 2: Participants' suggestions on how student's experience can be enriched during $\mathrm{CBME}$ at $\mathrm{BDH}$ 


\begin{tabular}{|c|c|c|}
\hline Themes & $\begin{array}{l}\text { Percentage } \\
\text { coverage } \\
(\%) \\
\end{array}$ & Some excerpt from participants responses \\
\hline $\begin{array}{c}\text { Increase duration of } \\
\text { training }\end{array}$ & 25.6 & $\begin{array}{l}\text { I would suggest a longer time in Botshabelo. } \\
\text { We would love more time at Botshabelo } \\
\text { Rotation can be made longer... } \\
\text { Make the rotation longer with a week or two }\end{array}$ \\
\hline Improved organisation & 10.4 & $\begin{array}{l}\text { Coordinate a better schedule... } \\
\text { The clinic schedule should be more task-structured } \\
\text { to make it easier to experience the full spectrum of } \\
\text { tasks in primary health care } \\
\text { Set time table hanging on wall in Doctors' rooms } \\
\text { so we all know where to go and when }\end{array}$ \\
\hline $\begin{array}{l}\text { Inclusion of formal } \\
\text { educational } \\
\text { programme in the } \\
\text { training }\end{array}$ & 8.4 & $\begin{array}{l}\text { Have a few more tutorials arranged where we } \\
\text { could learn new things } \\
\text { More lectures like Dr C's HIV lecture would be } \\
\text { fantastic } \\
\text { More education sessions } \\
\text { Perhaps specific lectures can be given.... }\end{array}$ \\
\hline $\begin{array}{c}\text { Improve doctors } \\
\text { attitude }\end{array}$ & 6.1 & $\begin{array}{l}\text { The doctors really should get more involved and } \\
\text { teach the students along with letting us go on our } \\
\text { own and just counter signing }\end{array}$ \\
\hline $\begin{array}{l}\text { Student debriefing on } \\
\text { roles and } \\
\text { responsibilities }\end{array}$ & 6.1 & $\begin{array}{l}\text { Perhaps an accurate briefing of what is expected in } \\
\text { clinics from students as... } \\
\text { The clinics could include an orientation into the } \\
\text { system... } \\
\text { Info on what you should be doing at clinics } \\
\text { Inform students what to prepare }\end{array}$ \\
\hline Review clinic visit & 5.7 & $\begin{array}{l}\text { Limit clinic days and use those days to do } \\
\text { something else in hospital } \\
\text { Clinic visits to be revised }\end{array}$ \\
\hline Review Log book & 2.8 & $\begin{array}{l}\text { Change logbook } \\
\text { Change the logbook as more of a guide for what } \\
\text { we can/should do - or at least, limit number of } \\
\text { signatures } \\
\text { Revise the log book - too many things aren't being } \\
\text { done... }\end{array}$ \\
\hline $\begin{array}{l}\text { Provide more hands- } \\
\text { on experience }\end{array}$ & 1.0 & $\begin{array}{l}\text { Students should be allowed to perform more } \\
\text { procedures } \\
\text { Be allowed to work more in surgery }\end{array}$ \\
\hline $\begin{array}{c}\text { Improve living } \\
\text { condition }\end{array}$ & 1.0 & $\begin{array}{l}\text { Adjoining bathroom and shower for students } \\
\text { Fix air conditioner } \\
\text { Bathrooms for students }\end{array}$ \\
\hline
\end{tabular}

\section{Figures}




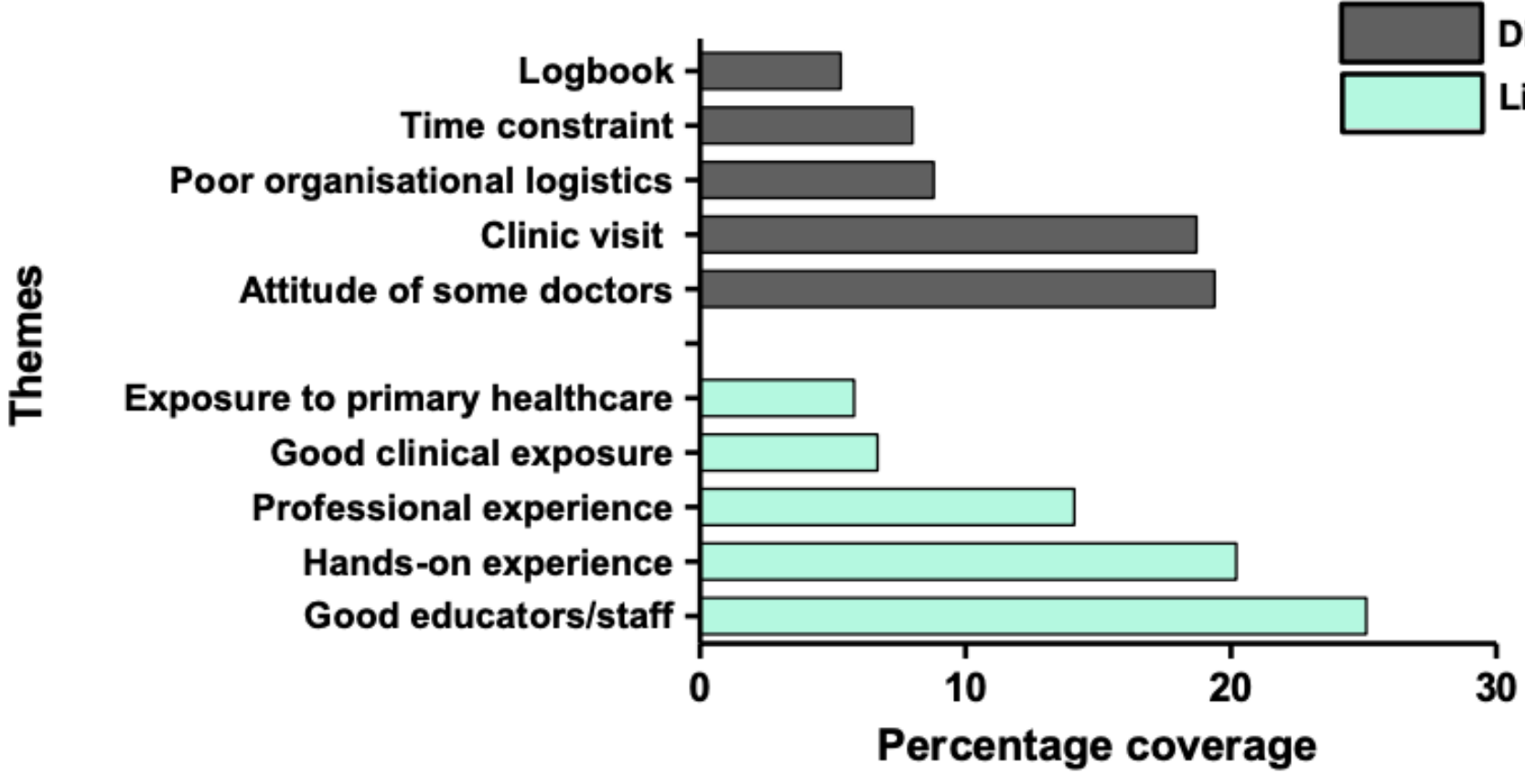

Figure 1

The five topmost themes in both "likes" and "dislikes" category.

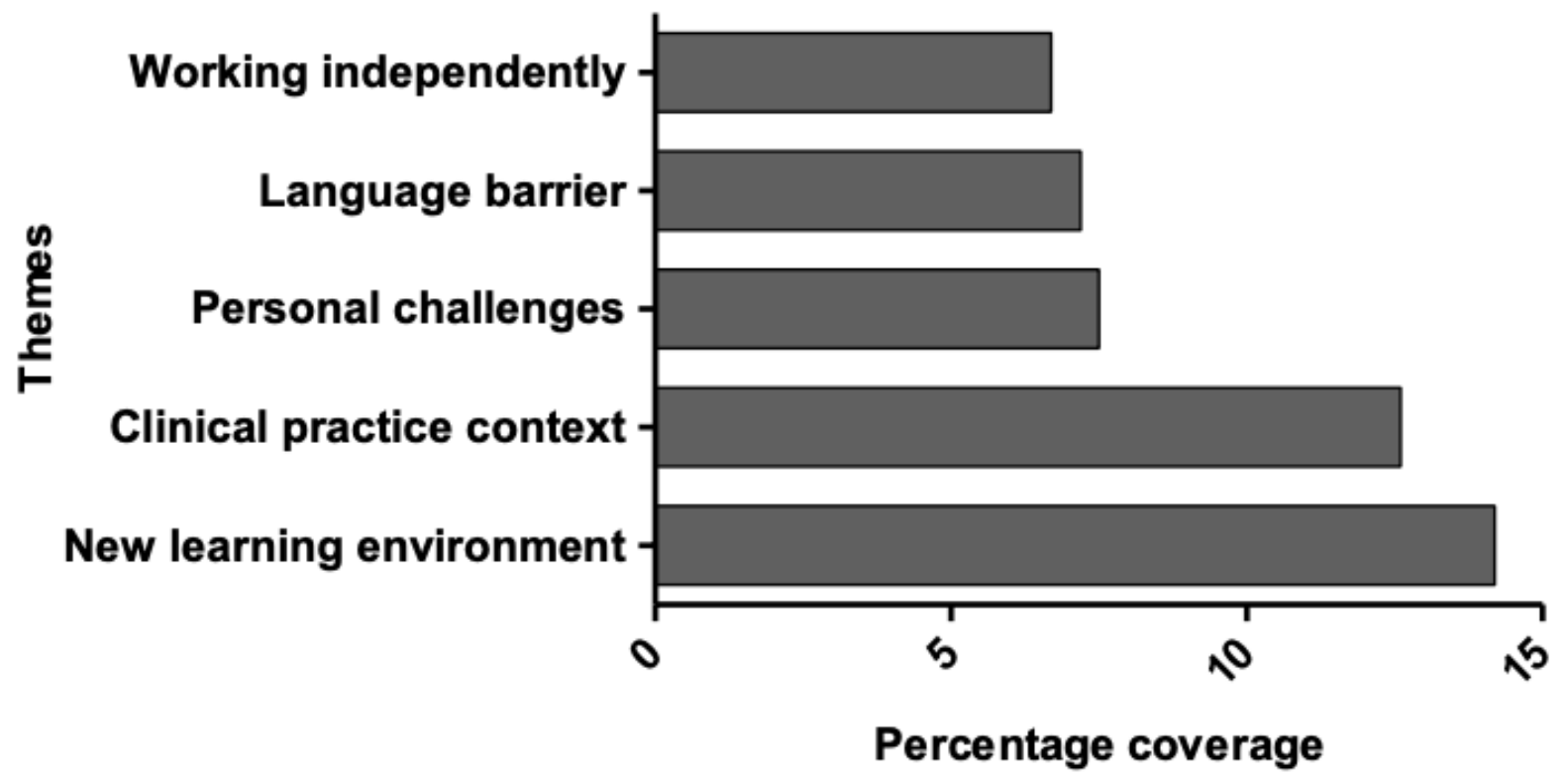


Figure 2

The five topmost challenges encountered by participants during their CBME posting in BDH

\section{Supplementary Files}

This is a list of supplementary files associated with this preprint. Click to download.

- Appendixl.docx 